\title{
Age, growth and organochlorines (HCB, DDTs and PCBs) in Mediterranean striped dolphins Stenella coeruleoalba stranded in 1988-1994 on the coasts of Italy
}

\author{
Letizia Marsilii ${ }^{1, *}$, Carolina Casini $^{2}$, Luca Marini ${ }^{3}$, Andrea Regoli ${ }^{4}$, Silvano Focardi ${ }^{1}$ \\ ${ }^{1}$ Dipartimento di Biologia Ambientale, Universita' di Siena, Via delle Cerchia 3, I-53100 Siena, Italy \\ ${ }^{2}$ Dipartimento di Biologia Animale e dell'Uomo, Universita' "La Sapienza”, Viale dell'Universita' 32, I-00185 Roma, Italy \\ ${ }^{3}$ Ufficio per i Diritti degli Animali, Comune di Roma, Viale del Giardino Zoologico 20, I-00197 Roma, Italy \\ ${ }^{4}$ Istituto Nazionale di Statistica, Via A. Ravà 150, I-00142 Roma, Italy
}

\begin{abstract}
This study was based on data from 62 specimens of Stenella coeruleoalba found stranded along the Italian coasts between 1988 and 1994. The age of each dolphin was determined by counting dentine growth layer groups in the teeth and a growth curve was plotted. Organochlorine contaminants (HCB, DDTs and PCBs) were analysed in the blubber, liver, brain and muscle of 25 of the dolphins. In all dolphins and all tissues analysed, HCB concentrations (ng $\mathrm{g}^{-1}$ dry welght) were the lowest and the PCBs were the highest, except in 1 blubber sample in which total DDTs were higher than PCBs. Correlations were sought between levels of these contaminants and age, sex, cause of death, locality and year of stranding.
\end{abstract}

KEY WORDS: Stenella coeruleoalba. Dolphin Organochlorines Mediterranean Sea Growth curve Teeth $\cdot$ Sex

\section{INTRODUCTION}

Cetaceans are under continuous pressure due to whaling, drowning in fishing nets, marine pollution and capture for aquariums. Against these odds, not all species of cetaceans are succeeding in their struggle to survive. Reports indicate that some species are on a gradual path to extinction. Many cetacean species, including the striped dolphin Stenella coeruleoalba, are located high in the marine food chain and therefore accumulate high levels of fat-soluble compounds such as chlorinated hydrocarbons (Tanabe et al. 1981a, Borrell 1993, Marcovecchio et al. 1994, Marsili \& Focardi 1997). The ecotoxicological risk of some species of cetaceans is also related to their 'biochemical vulnerability' to lipophilic xenobiotics: the fact that they have

\footnotetext{
•E-mail: marsilil@unisi.it
}

a lower cytochrome P-450 activity than terrestrial mammals (Tanabe et al. 1988, Duinker et al. 1989, Watanabe et al. 1989, Fossi et al. 1992) Tanabe \& Tatsukawa (1992) reported that '.. these animals have a low capacity for degradation of organochlorines due to the specific mode of their cytochrome P-450 enzyme system' Many references indicate the possibility of using these animals as bioindicators of environmental contamination of relatively limited areas $\left(O^{\prime}\right.$ Shea et al. 1980, Martineau et al. 1987, Geraci 1989, Loganathan et al. 1990, Marsili \& Focardi 1996). Data obtained for the Mediterranean Sea cetaceans are quite alarming (Alzieu \& Duguy 1979, Aguilar \& Borrell 1994a, b, Marsili \& Focardi 1996, Marsili \& Focardi 1997). Such xenobiotics are known to have effects on pinnipeds which include reproductive anomalies (Le Boeuf \& Bonnell 1971, Helle et al. 1976a, Olsson 1978, Addison 1989), uterine tumours (Helle et al. 1976b, Baker 1989) and abnormal skeletal development (Bergman et al. 1986. 
Zakharov \& Yablokov 1990). Since many cetaceans have a similar life style and diet to pinnipeds, they run similar risks.

The stranding of cetaceans along the Mediterranean coasts is a normal event, since animals dying of natural causes, such as old age, or as a result of accidents, such as injury by boats, ingestion of foreign objects (including plastic bags) or drowning in fishing nets, either sink or drift ashore. In recent years, there have been episodes of large-scale mortality of dolphins (Bortolotto et al. 1992. Aguilar \& Raga 1993, Van Bressen et al. 1993). The cause of death of some stranded specimens is evident, e.g. wounds due to harpooning or impact with power boats; for others it cannot be established even after careful study.

The aim of the present study was to investigate the degree to which xenobiotics, such as hexachlorobenzene (HCB), dichlorodiphenyltrichloroethane (DDT) and its metabolites, and polychlorobiphenyls (PCBs), play a role in the death of striped dolphins. It is known that large differences exist in the accumulation of these substances in specimens of the same species. These differences are related to parameters such as age, sex, health and geographical location.

\section{MATERIALS AND METHODS}

Between 1988 and 1994, 62 specimens of Stenella coeruleoalba were collected on the Italian coasts and sent to the Department of Environmental Biology of Siena for chemical analysis and age determination (Table 1). Age was also determined at the University 'La Sapienza' of Rome (Casini 1995).

Tooth preparation and age determination. Sixtytwo mandibles of stranded dolphins were obtained and the teeth were collected after complete putrefaction of the mandible by enzyme digestion in water. The teeth were cleaned and stored in neutral-buffered $4 \%$ formalin. The teeth were prepared for examination as described by Lockyer et al. (1981) and Myrick et al. (1983). Tooth sections $24 \mu \mathrm{m}$ thick (about 100 per tooth) were obtained with a 'sledge-type freezing' microtome. They were stained with Mayer's haematoxylin and mounted in DPX medium. Three of the authors (L. M., C. C. \& L. M.) independently examined the sections directly on slides under the light microscope (Wild M8: 50x) and in photographs taken with the same microscope using a Pentax P30N camera with a Pentax-A 28-80 mm zoom lens. Age was determined by counting growth layer groups (GLG) in tooth dentine. GLG were first used as indicators of age in Stenella coeruleoalba by Nishiwaki \& Yagi (1953). A GLG consists of 2 fine translucent layers and 2 thick dark layers of dentine and represents a year of
Table 1 Stenella coeruleoalba. Specimens in which age was determined by tooth analysis $(n=62)$

\begin{tabular}{|c|c|c|c|c|c|}
\hline ID no. & Sex & $\begin{array}{l}\text { Length } \\
(\mathrm{cm})\end{array}$ & $\begin{array}{l}\text { Age } \\
(y r)\end{array}$ & Sea & $\begin{array}{l}\text { Year of } \\
\text { stranding }\end{array}$ \\
\hline $66 / 93$ & $M$ & 100 & 2.0 & Tyrrhenian Sea & 1993 \\
\hline So 8 & $\mathrm{~F}$ & 105 & 1.0 & Tyrrhenian Sea & 1991 \\
\hline $12 / 91$ & $M$ & 110 & 1.5 & Tyrrhenian Sea & 1991 \\
\hline $93 / 93$ & $F$ & 112 & 1.0 & Tyrrhenian Sea & 1993 \\
\hline $7 / 92$ & $F$ & 116 & 1.5 & Tyrrhenian Sea & 1992 \\
\hline $14 / 91$ & $M$ & 122 & 0.5 & Tyrrhenian Sea & 1991 \\
\hline 70 & $M$ & 125 & 1.0 & Tyrrhenian Sea & 1993 \\
\hline $10 / 91$ & $F$ & 128 & 2.0 & Tyrrhenian Sea & 1991 \\
\hline 63 & $M$ & 130 & 2.5 & Adriatic Sea & 1991 \\
\hline 42 & $M$ & 152 & 2.0 & Adriatic Sea & 1991 \\
\hline $13 / 88$ & $\mathrm{x}$ & 154 & 2.5 & Tyrrhenian Sea & 1988 \\
\hline 48 & $M$ & 157 & 3.0 & Adriatic Sea & 1991 \\
\hline 46 & $F$ & 162 & 3.5 & Adriatic Sea & 1991 \\
\hline P01 & $M$ & 163 & 15.0 & Adriatic Sea & 1991 \\
\hline 69 & $\hat{M}$ & 165 & 50 & Tyrrhenian Sea & 1993 \\
\hline 894 & $M$ & 165 & 2.0 & Ionian Sea & 1991 \\
\hline $28 / 90$ & $M$ & 166 & 5.5 & Tyrrhenian Sea & 1990 \\
\hline 27 & $M$ & 173 & 5.0 & Adriatic Sea & 1991 \\
\hline P15 & M & 174 & 7.0 & Tyrrhenian Sea & 1992 \\
\hline $20 / 89$ & M & 175 & 13.0 & Tyrrhenian Sea & 1989 \\
\hline 34 & $M$ & 1.77 & 3.0 & Adriatic Sea & 1991 \\
\hline 49 & $M$ & 186 & 4.0 & Ionian Sea & 1991 \\
\hline A5 & $\dot{M}$ & 188 & 4.0 & Tyrrhenian Sea & 1991 \\
\hline 51 & M & 190 & 6.0 & Adriatic Sea & 1991 \\
\hline $1 / 88$ & $M$ & 192 & 8.0 & Tyrrhenian Sea & 1988 \\
\hline 38 & $\mathrm{~F}$ & 192 & 12.0 & Ionian Sea & 1991 \\
\hline 39 & $\mathrm{~F}$ & 192 & 12.0 & Adriatic Sea & 1991 \\
\hline 28 & $\mathrm{M}$ & 193 & 13.0 & Adriatic Sea & 1991 \\
\hline $4 / 94$ & $\mathrm{X}$ & 194 & 11.0 & Tyrrhenian Sea & 1994 \\
\hline 47 & $\mathrm{~F}$ & 194 & 15.0 & Adriatic Sea & 1991 \\
\hline A.13 & $M$ & 195 & 13.0 & Ionian Sea & 1991 \\
\hline $65 / 93$ & $F$ & 195 & 12.0 & Tyrrhenian Sea & 1993 \\
\hline 43 & M & 195 & 9.0 & Adriatic Sea & 1991 \\
\hline 71 & M & 195 & 15.0 & Tyrrhenian Sea & 1991 \\
\hline $3 / 94$ & M & 196 & 7.0 & Tyrrhenian Sea & 1994 \\
\hline $19 / 92$ & $\mathrm{~F}$ & 196 & 18.0 & Tyrrhenian Sea & 1992 \\
\hline $92 / 93$ & $M$ & 196 & 9.0 & Tyrrhenian Sea & 1993 \\
\hline 40 & $F$ & 196 & 7.5 & Adriatic Sea & 1991 \\
\hline 41 & M & 197 & 13.0 & Adriatic Sea & 1991 \\
\hline 29 & M & 198 & 11.0 & Adriatic Sea & 1991 \\
\hline 862 & M & 198 & 23.0 & Tyrrhenian Sea & 1991 \\
\hline 32 & $M$ & 199 & 9.0 & Adriatic Sea & 1991 \\
\hline 54 & M & 199 & 14.0 & Adriatic Sea & 1991 \\
\hline 863 & $F$ & 200 & 23.0 & Ionian Sea & 1991 \\
\hline 864 & M & 200 & 10.0 & Ionian Sea & 1991 \\
\hline 870 & M & 200 & 18.0 & Adriatic Sea & 1991 \\
\hline P04 & $F$ & 201 & 3.0 & Adriatic Sea & 1991 \\
\hline $\mathrm{PO} 2$ & $M$ & 201 & 15.0 & Adriatic Sea & 1991 \\
\hline 62 & $M$ & 201 & 23.0 & Adriatic Sea & 1991 \\
\hline 53 & $\mathrm{~F}$ & 203 & 15.0 & Adriatic Sea & 1991 \\
\hline 59 & M & 203 & 28.0 & Adriatic Sea & 1991 \\
\hline 56 & $\mathrm{~F}$ & 204 & 16.0 & Adriatic Sea & 1991 \\
\hline 60 & $\mathrm{~F}$ & 204 & 18.0 & Adriatic Sea & 1991 \\
\hline S06 & $\mathrm{F}$ & 205 & 7.0 & Jonian Sea & 1991. \\
\hline 50 & $F$ & 205 & 16.0 & Adriatic Sea & 1991 \\
\hline 35 & $F$ & 207 & 20.0 & Adriatic Sea & 1991 \\
\hline $9 / 89$ & $\hat{\mathrm{M}}$ & 210 & 12.0 & Tyrrhenian Sea & 1989 \\
\hline 18 & $\mathrm{M}$ & 212 & 25.0 & Ionian Sea & 1991 \\
\hline 52 & $\mathrm{~F}$ & 213 & 23.0 & Adriatic Sea & 1991 \\
\hline $27 / 90$ & $\mathrm{M}$ & 215 & 18.0 & Tyrrhenian Sea & 1990 \\
\hline 36 & $F$ & 220 & 25.0 & A.driatic Sea & 1991 \\
\hline 37 & $M$ & 220 & 20.0 & Adriatic Sea & 1991 \\
\hline
\end{tabular}


growth. In the cement it consists of a translucent layer and a darker layer (Kasuya 1972, Perrin \& Myrick 1980) Age was determined by comparison of the counts of the 3 observers. If all 3 counted the same number of GLG, the age was unanimous. If the number of GLG differed by no more than 2 between the 3 observers, the mean of the 3 values was taken. If 2 observers counted the same number of GLG and the third count differed by no more than 3, the age established by the first 2 was adopted. In other cases, another tooth of the same dolphin was prepared and new sections counted.

Chemical analysis. Organs and tissues (liver, muscle, blubber and brain), in different states of conservation, depending on how long the dolphins had been dead, were frozen and stored between -20 and $-30^{\circ} \mathrm{C}$. Before chemical analysis, about $20 \mathrm{~g}$ of tissue was lyophilised in an Edwards freeze drier. To calculate water content, a sample of about $5 \mathrm{~g}$ was placed in an oven at $110^{\circ} \mathrm{C}$ for $24 \mathrm{~h}$. The percentage water content (mean $\pm \mathrm{SD}$ ) in the various tissues was as follows: liver $(n=5), 72.5 \pm 9.70 \%$; muscle ( $n=5), 74.2 \pm 5.50 \%$; brain $(n=4), 79.3 \pm 5.80 \%$; blubber $(n=5), 35.5 \pm$ $19.3 \%$

Aliquats of 1 to $1.5 \mathrm{~g}$ of freeze-dried material were extracted with $n$-hexane in preextracted thimbles in a Soxhlet apparatus for $9 \mathrm{~h}$. The samples were then purified with sulphuric acid (Murphy 1972) to obtain a first lipid sedimentation. The extract was run on a liquid chromatography column containing Florisil that had been dried for $1 \mathrm{~h}$ in an oven at $110^{\circ} \mathrm{C}$. This further purified the apolar phase of lipids that could not be saponified, such as steroids like cholesterol. The extracted organic matter (EOM\%) from freeze-dried samples was as follows: liver ( $\mathrm{n}=19), 22.0 \pm 16.1 \%$; muscle $(\mathrm{n}=20), 10.7 \pm 4.7 \%$; brain $(\mathrm{n}=17), 43.6 \pm$ $5.7 \%$; blubber $(\mathrm{n}=24), 82.5 \pm 16.8 \%$.

The analytical method used was high resolution capillary gas chromatography with a ${ }^{63} \mathrm{Ni}$ electron capture detector and an SBP-5 bonded phase capillary column (30 $\mathrm{m}$ long, $0.2 \mathrm{~mm}$ inner diameter). The carrier gas was $\mathrm{N}_{2}$ with a head pressure of $105 \mathrm{kPa}$ (splitting ratio $50 / 1)$. The scavenger gas was argon/methane (95/5) at $40 \mathrm{ml} \mathrm{min}{ }^{-1}$ Oven temperature was $100^{\circ} \mathrm{C}$ for $10 \mathrm{~min}$, after which it was increased to $280^{\circ} \mathrm{C}$ at $5^{\circ} \mathrm{C} \mathrm{min}^{-1}$. Injector and detector temperatures were 200 and $280^{\circ} \mathrm{C}$, respectively.

A mixture of specific isomers was used to calibrate the system, evaluate recovery and confirm the results, which were expressed in $n g g^{-1}$ or $\mu g g^{-1}$, dry weight (d.w.) or lipid basis (l.b.). Recoveries were calculated by adding known quantities of standard to homogeneous replicates of the same sample. Recovery varied from a minimum of $85 \%$ to a maximum of $93 \%$ according to the matrix. The blank was evaluated by extracting an empty thimble once every 11 samples. The precision of the method was measured on 5 homogeneous replicates, calculating the coefficient of variation of the results obtained. It was less than $9 \%$ for all compounds analysed. To ensure accuracy, intercalibration exercises were performed with appropriate standards. We detected $\mathrm{HCB}, o p^{\prime} \mathrm{DDT}$ and $p p^{\prime} \mathrm{DDT}$ and their metabolites ( $p p^{\prime}$ and $o p^{\prime} \mathrm{DDD}, p p^{\prime}$ and $o p^{\prime} D D E$ ) and identified 30 PCB congeners (Table 2). The congeners constituted $80 \%$ of the total peak area of PCBs in all tissues

Statistical analysis. The data were processed by summary statistics and analysis of variance (ANOVA) using Statgraphics software (Statistical Graphics Corp.). The parameters considered were length, sex, age, cause of death, site and year of stranding. The significance level was $\mathrm{p}<0.05$. The parameter $r$ of the growth curve was calculated by an iterative procedure, namely NLIN of the SAS software package (SA.S) STAT, Release 6.04 Edition, SAS Institute Inc.).

Table 2. IUPAC number and structure of the $30 \mathrm{PCB}$ congeners detected in all samples

\begin{tabular}{|ll|}
\hline IUPAC number & Structure \\
\hline Pentachlorobiphenyls & \\
95 & $22^{\prime} 35^{\prime} 6$ \\
99 & $22^{\prime} 44^{\prime} 5$ \\
101 & $2^{\prime} 455^{\prime}$ \\
118 & $23^{\prime} 44^{\prime} 5$ \\
Hexachlorobiphenyls & \\
128 & $22^{\prime} 33^{\prime} 44^{\prime}$ \\
135 & $22^{\prime} 33^{\prime} 56^{\prime}$ \\
138 & $22^{\prime} 344^{\prime} 5^{\prime}$ \\
141 & $22^{\prime} 3455^{\prime}$ \\
144 & $22^{\prime} 345^{\prime} 6$ \\
146 & $22^{\prime} 34^{\prime} 55^{\prime}$ \\
149 & $22^{\prime} 34^{\prime} 5^{\prime} 6$ \\
151 & $22^{\prime} 355^{\prime} 6$ \\
153 & $22^{\prime} 44^{\prime} 55^{\prime}$ \\
156 & $233^{\prime} 44^{\prime} 5$ \\
Heptachlorobiphenyls & \\
170 & $22^{\prime} 33^{\prime} 44^{\prime} 5$ \\
171 & $22^{\prime} 33^{\prime} 44^{\prime} 6$ \\
172 & $22^{\prime} 33^{\prime} 455^{\prime}$ \\
174 & $22^{\prime} 33^{\prime} 456^{\prime}$ \\
177 & $22^{\prime} 33^{\prime} 4^{\prime} 56$ \\
178 & $22^{\prime} 33^{\prime} 55^{\prime} 6$ \\
180 & $22^{\prime} 344^{\prime} 55^{\prime}$ \\
183 & $22^{\prime} 344^{\prime} 5^{\prime} 6$ \\
187 & $22^{\prime} 34^{\prime} 55^{\prime} 6$ \\
Octachlorobiphenyls & \\
194 & $22^{\prime} 33^{\prime} 44^{\prime} 55^{\prime}$ \\
195 & $22^{\prime} 33^{\prime} 44^{\prime} 56$ \\
196 & $22^{\prime} 33^{\prime} 44^{\prime} 5^{\prime} 6$ \\
199 & $22^{\prime} 33^{\prime} 4566^{\prime}$ \\
201 & $22^{\prime} 33^{\prime} 4^{\prime} 55^{\prime} 6$ \\
202 & $22^{\prime} 33^{\prime} 555^{\prime} 66^{\prime}$ \\
Nonachlorobiphenyls & \\
206 & $22^{\prime} 33^{\prime} 44^{\prime} 55^{\prime} 6$ \\
\hline
\end{tabular}




\section{RESULTS AND DISCUSSION}

\section{Growth curve}

A growth curve for Stenella coeruleoalba in the Mediterranean was plotted on the basis of the age and length data. The equation relating length and age is based on a mean length at birth of $90 \mathrm{~cm}$ (Notarbartolo di Sciara \& Demma 1994) and a mean length of adults (> 9 yr) of $200 \mathrm{~cm}$, ignoring sex differences (males are about $10 \mathrm{~cm}$ longer than females) (Notarbartolo di Sciara \& Demma 1994). The equation is:

$$
\frac{\mathrm{d} L}{\mathrm{~d} t}=r L \frac{K-L}{K}
$$

where $L$ is body length ( $\mathrm{cm}$ ), $K$ is the mean length of adult specimens $(\mathrm{cm}), r$ is the growth rate constant $\left(t^{-1}\right)$ and $t$ is age $(y r)$. Integrating, we obtain

$$
L_{(t)}=\frac{K}{1+e^{|d-r t|}}
$$

where $a=\ln [(K-L) / L]$ for $t=0$ is the integration constant. Since at birth $(t=0)$ a striped dolphin is about $90 \mathrm{~cm}$ long, $a=\operatorname{In}[(200-90) / 90]=0.201$

If $Y$ is body length $(\mathrm{cm})$ and $X$ age $(y r)$ we obtain.

$$
Y=200 /\left[1+\mathrm{e}^{\mid 0.201-r r_{1}}\right]
$$

The parameter $r(r=0.5115)$ was calculated by nonlinear regression analysis using the least squares method. The asymptotic standard error of $r$ is very low (0.0355) so that parameter and the relation are significant. The final equation is therefore:

$$
Y=200 /\left[1+e^{10.201-0.5115 x_{1}}\right]
$$

The resulting curve represents the relationship between body length and age (Fig. 1)

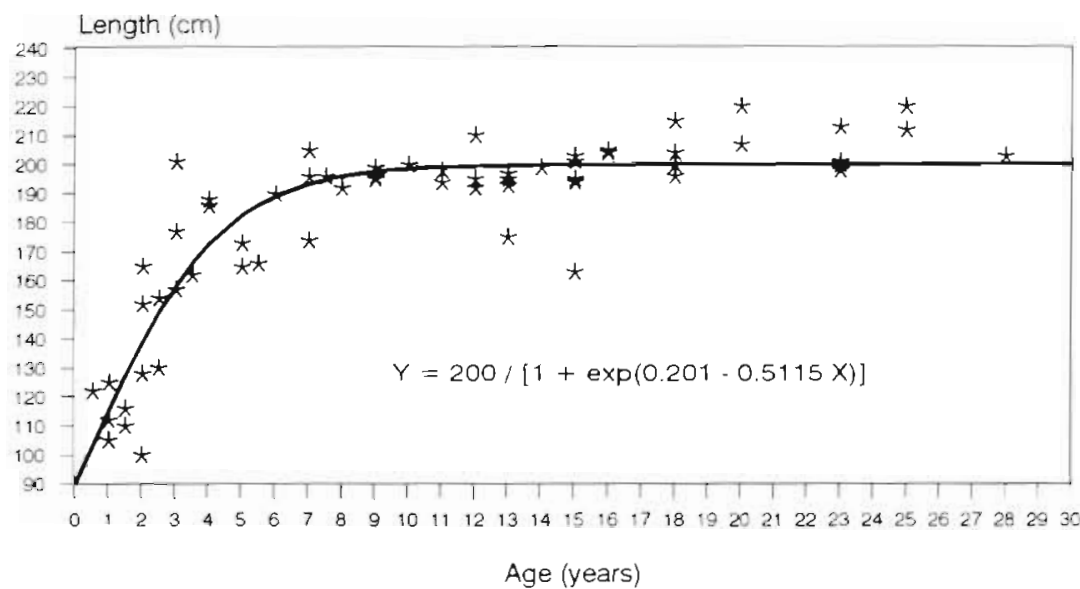

Fig. 1. Stenella coerunleodba. Growth curve of dolphins in the Mediterranean Sea. Y length; $X$ : age
Kasuya (1972) formulated the first growth curve for Stenella coeruleoalba in the Pacific Ocean based on 218 females and 191 males. With such a large number of specimens, he was able to distinguish male and female growth. He found that the mean length of males was about $15 \mathrm{~cm}$ greater than that of females. Mean length at birth was estimated to be $99.8 \mathrm{~cm}$. One-yearold specimens measured $164 \mathrm{~cm}$ and the first sex difterences became evident at 2 yr and were distinct by 6 yr Growth rate of females increased between the ages of 7 and $8 \mathrm{yr}$, at which time they wore slightly longer than males. Females then grew slowly towards an asymptote of $225.3 \mathrm{~cm}$ at about $17 \mathrm{yr}$. Male growth rate tended to slow after $10 \mathrm{yr}$, body length approaching an asymptote of $236 \mathrm{~cm}$ at about $21 \mathrm{yr}$ (Kasuya 1976). Bryden (1986) reports a year of fast growth in females around the age of 7 to $8 \mathrm{yr}$ and $2 \mathrm{yr}$ of fast growth in males around the age of 11 to $13 y r$.

The growth curve of Stenella coeruleoalba in the Mediterranean (Fig. 1) shows that growth is quite slow in the first year and is followed by a rapid increase in size up to a plateau at physical maturity, which seems to be attained at about $8 \mathrm{yr}$. The curve is similar to that obtained for ocean dolphins (Kasuya 1972, 1976); the only difference is the time taken to reach physical maturity. Since ocean striped dolphins are larger than their Mediterranean counterparts, they presumably take longer to reach full size

\section{Correlation between organochlorine levels and age, sex, cause of death, site and year of stranding}

Twenty-five stranded striped dolphins (all of known age and 23 of known sex) were sampled for organochlorine analysis. The types of tissue (blubber, muscle, brain and liver) are the most commonly used for this kind of analysis and hence the most suitable for comparison with data in the literature.

Since males and females reach sexual maturity at about 9 yr (Bryden 1986, Notarbartolo di Sciara \& Demma 1994), we can deduce that 14 of the 25 dolphins were sexually immature; the other 11 were of potentially reproductive age. Unfortunately, there were no dolphins over 18 yr of age, despite the fact that striped dolphins can live up to $40 \mathrm{yr}$ (Notarbartolo di Sciara \& Demma 1994) and only 2 of the sexually mature dolphins were females. The fact that 2 sexually mature specimens were females is important because 
females lose more than $90 \%$ of their total body burden of organochlorines during pregnancy and lactation (Tanabe et al. 1981b, 1982). This is linked to the fact that the milk of these marine mammals contains very high levels of fats, mostly triglycerides. The milk of Stenella coeruleoalba, for instance, contains $258 \mathrm{mg}$ $\mathrm{g}^{-1}$ of triglycerides out of $280 \mathrm{mg} \mathrm{g}^{-1}$ total fats (Kawai \& Fukushima 1981). Tanabe et al. (1981b) estimated that a pregnancy followed by 6 to 7 mo of lactation enables a female of $S$. coeruleoalba to lose $4.7 \%$ during pregnancy and $95 \%$ during lactation of her total body burden of DDT, and $4 \%$ during pregnancy and $92 \%$ during lactation of that of PCBs, respectively. The 2 adult females analysed in this study will be referred to as $A$ and B: A was 12 and B 18 yr of age. On average. females have a calf every 3 yr (Cagnolaro et al. 1983). This means that $A$ could not have had more than 2 calves and $B$ not more than 4. A was carrying a foetus $40 \mathrm{~cm}$ long when she died, but it was not possible to determine whether this was her first or second pregnancy.

The year and site of stranding are important parameters in view of the die-off of dolphins that occurred along the Mediterranean coasts in 1990 and 1991 (Bortolotto et al. 1992, Aguilar \& Raga 1993, Van Bressen et al. 1993). A virus of the genus Morbillivirus (Domingo et al. 1991) was identified in dolphins stranded during this period. The virus affects the lungs and was probably one cause of the die-off (Aguilar \& Borrell 1994a). Since PCBs depress the immune svstem and are toxic to the liver (Loose et al. 1977, Brouwer et al. 1989, Vos \& Luster 1989), they are often accused of facilitating disease. In line with this concept, it has been found that organs and tissues with Morbillivirus infection had organochlorine levels several times higher than those found in dolphins dying of unknown causes (e.g old age) or due to accidents (Borrell \& Aguilar 1991, Aguilar \& Borrell 1994a, Marsili \& Focardi 1997). Of the 25 dolphins used for age determination and ecotoxicological investigations, $48 \%$ died during 1990 and 1991, $16 \%$ before 1990 and $36 \%$ after 1991 . Although pathology and parasitology studies were performed on many specimens, Morbillivirus was rarely isolated. On the other hand, many larval forms of cestodes, nematodes and trematodes were found. Anatomical pathology revealed many cases of sub-acute pneumonia (Podestà et al. 1992). These factors must be considered in correlating contaminant levels with dolphin age. Except for those dying in accidents, the dolphins were not in good health.

Table 3 gives the chlorinated hydrocarbon concentrations found in blubber, liver, brain and muscle of dolphins of known age. In all dolphins, HCB levels were the lowest and PCBs were the highest, except in 1 blubber sample (dolphin PO2) in which total DDTs were higher than PCBs. The PCBs:DDTs ratio was greater than 1 in all organs and tissues, with a minimum in blubber [arithmetic mean 2.05, standard deviation (SD) 0.93] and a maximum in muscle (arithmetic mean $4.10, \mathrm{SD} 2.62$ ). The fact that this ratio was always greater than 1 reflects the fact that the use of DDT has been restricted in the Mediterranean basin since the 1970s, whereas PCBs are still used in great quantities.

The main tissue of accumulation was blubber (Table 3). Only 2 dolphins (20/89 and 9/89) had higher DDT (the former) and PCB (both) levels in the brain, and 3 others $(19 / 92,65 / 93$ and 66/93) had higher DDT (the latter 2) and PCB (all) levels in the liver

As mentioned in 'Materials and methods', the 4 tissues analysed differ considerably in fat content. Since the contaminants of man-made origin analysed in this study are lipophilic compounds, the data was expressed on a lipid basis (1.b.) by multiplying the dry weight content by the respective EOM\%. DDTs and PCBs were summed for each tissue, dolphin by dolphin. Then total DDTs and PCBs were calculated by summing the data of the 4 tissues (blubber DDTs+ PCBs + liver DDTs+PCBs + brain DDTs+PCBs + muscle DDTs+PCBs). This parameter was used as a measure of total input of organochlorines and was plotted against age for the dolphins whose age we had been able to determine. DDTs+PCBs were plotted against age to give the distribution shown in Fig. 2A. Males were generally located in the upper part of the distribution. Their input of xenobiotics increased with age, though specimens in the age range from 6 to $12 \mathrm{yr}$ had lower mean levels (arithmetic mean $431 \mathrm{\mu g} \mathrm{g}^{-1}$ l.b., SD 506, $\mathrm{n}=4$ ) than those aged 0 to $6 \mathrm{yr}$ (arithmetic mean $664 \mu \mathrm{g} \mathrm{g}^{-1}$ l.b., SD 326, $\mathrm{n}=5$ ). Males over 12 yr of age had the highest levels (arithmetic mean $2068 \mu \mathrm{g} \mathrm{g}^{-1}, \mathrm{SD} 1845, \mathrm{n}=6$ ).

Females under 7 yr of age had lower PCBs+DDTs than the corresponding males (arithmetic mean $220 \mu \mathrm{g}$ $\mathrm{g}^{-1}$ 1.b., $\mathrm{SD} 114, \mathrm{n}=5$ ). In the intermediate age range there was only 1 female $\left(182 \mu \mathrm{g} \mathrm{g}^{-1}\right.$ l.b.). Strangely, the 2 females in the upper age range had very high organochlorine levels (arithmetic mean $1735 \mathrm{\mu g} \mathrm{g}^{-1}$ 1.b., SD 201), higher than all the other females and not significantly lower than males in the same age range. We had expected lower levels in the older females on the basis of reports that females pass part of their body burden of xenobiotics to their young during pregnancy and lactation (Tanabe et al. 1981b, 1982). We cannot explain why adult females $A$ and $B$ had such high levels of organochlorines because their histories are not known. Two hypotheses are possible: since female A was pregnant when she died, it may have been her first pregnancy; female B may have been sterile, and in any case was not pregnant. Unfortunately the reproductive organs were not examined to verify these 
Table 3. Concentrations of organochlorines in different tissues of specimens of Stenella coeruleoalba of known age. EOM"\%, percentage extracted organic matter

\begin{tabular}{|c|c|c|c|c|c|c|c|c|c|c|c|c|c|c|c|c|}
\hline \multirow{2}{*}{ ID no. } & \multicolumn{4}{|c|}{ Blubber (ng $\left.g^{-1} \mathrm{~d} . \mathrm{w}.\right)$} & \multicolumn{4}{|c|}{ Liver $\left(n g \mathrm{~g}^{-1} \mathrm{~d}, \mathrm{w}\right)$} & \multicolumn{4}{|c|}{ Brain (ng g d.w.) } & \multicolumn{4}{|c|}{ Muscle ing g ${ }^{-1} \mathrm{~d} . \mathrm{w}$. ) } \\
\hline & EOM & $\% \mathrm{HCB}$ & DDTs & PCBs & $\mathrm{EOM}$ & $\% \mathrm{HCB}$ & DDTs & PCBs & $\mathrm{EOM}^{\circ}$ & $\mathrm{HCB}$ & DDTs & $\mathrm{PCBS}$ & $\mathrm{EOM} \%$ & $\mathrm{HCB}$ & DDTs & PCBS \\
\hline $1 / 88$ & 80 & 186 & 8507 & 16564 & 18 & 106 & 4861 & 8603 & 45 & 27 & 756 & 1512 & 16 & 7 & 367 & 971 \\
\hline $13 / 88$ & 80 & 59 & 4905 & 23993 & - & - & - & - & 43 & 79 & 767 & 2137 & 20 & 9 & 654 & 5331 \\
\hline $9 / 89$ & 80 & 294 & 22071 & 34607 & 18 & 62 & 6167 & 13756 & 39 & 370 & 18860 & 42700 & 16 & 7 & 1128 & 1801 \\
\hline $20 / 89$ & 80 & 16 & 5725 & 9204 & 18 & 21 & 623 & 1432 & 44 & 105 & 13540 & 40115 & 16 & 18 & 234 & 741 \\
\hline $27 / 90$ & 36 & 911 & 207821 & 573262 & 10 & $98=$ & 58611 & 172940 & 42 & 32 & 761 & 37629 & 3 & 9 & 3023 & 16599 \\
\hline $28 / 90$ & 88 & 307 & 72206 & 157734 & 8 & 50 & 7528 & 27261 & 32 & 25 & 3197 & 5670 & 6 & 5 & 658 & 2393 \\
\hline $10 / 91$ & 95 & 10091 & 33384 & 69499 & 48 & 52 & 13962 & 21161 & 47 & 111. & 3853 & 9020 & 12 & 160 & 3051 & 12190 \\
\hline $12 / 91$ & 100 & 1663 & 26373 & 42508 & - & - & - & - & 52 & 171 & 1934 & 8622 & 14 & 69 & 4775 & 2386 \\
\hline $14 / 91$ & 91 & 407 & 138116 & 214238 & 56 & $199=$ & 36755 & 46038 & 41 & 18 & 1320 & 2839 & 11 & 13 & 582 & 2070 \\
\hline $7 / 92$ & 100 & 341 & 34209 & 77616 & 11 & 187 & 1678 & 7059 & 38 & 74 & 961 & 4399 & 18 & 51 & 2341 & 6840 \\
\hline $19 / 92$ & 98 & 3896 & 165189 & 183817 & 29 & 119 & 82110 & 246702 & 47 & 295 & 13452 & 29254 & 4 & 10 & 3293 & 8562 \\
\hline $65 / 93$ & 94 & 189 & 23665 & 87836 & 15 & 260 & 27988 & 126560 & 51 & 33 & 3251 & 11084 & 10 & 122 & 3129 & 38439 \\
\hline $66 / 93$ & 95 & 698 & 32277 & 104379 & 66 & 798 & 46865 & 300993 & 47 & 33 & 969 & 4107 & 12 & 156 & 3280 & 26712 \\
\hline $92 / 93$ & 100 & 7916 & 54726 & 82918 & 27 & 108 & 4633 & 13352 & 52 & 29 & 2880 & 4582 & 7 & 51 & 972 & 2993 \\
\hline $93 / 93$ & 92 & 1874 & 24469 & 46461 & 17 & 96 & 3401 & 9669 & 35 & 38 & 1130 & 3201 & 8 & 48 & 2495 & 7941 \\
\hline $3 / 94$ & 96 & 545 & 35797 & 52833 & 13 & 27 & 1464 & 3476 & 38 & 42 & 1768 & 6795 & 7 & 114 & 877 & 2511 \\
\hline $4 / 94$ & 98 & 1146 & 44928 & 91729 & - & - & - & - & 48 & 607 & 1760 & 3211 & 6 & 24 & 1097 & 3224 \\
\hline A5 & 49 & 2283 & 122310 & 261244 & 13 & 79 & 2116 & 6744 & - & - & - & - & 11 & 111 & 1043 & 4970 \\
\hline A 13 & 79 & 2301 & 349964 & 469513 & 11 & 735 & 53317 & 136354 & - & - & - & - & 6 & 12 & 2060 & 4.008 \\
\hline P01 & 58 & 271 & 61409 & 85806 & - & - & - & - & - & - & - & - & - & - & - & - \\
\hline P02 & 72 & 491 & 260041 & 185704 & 12 & 830 & 42281 & 49735 & - & - & - & - & - & - & - & - \\
\hline P04 & 61 & 296 & 14790 & 46388 & 12 & 1329 & 2216 & 4824 & - & - & - & - & - & - & - & - \\
\hline P15 & - & - & - & - & 16 & 21 & 2598 & 4045 & - & - & - & - & 10 & 5 & 666 & 2091 \\
\hline S06 & 78 & 459 & 63515 & 78107 & - & - & - & - & - & - & - & - & - & - & - & - \\
\hline S08 & 79 & 192 & 14961 & 26695 & - & - & - & - & - & - & - & - & - & - & - & - \\
\hline
\end{tabular}
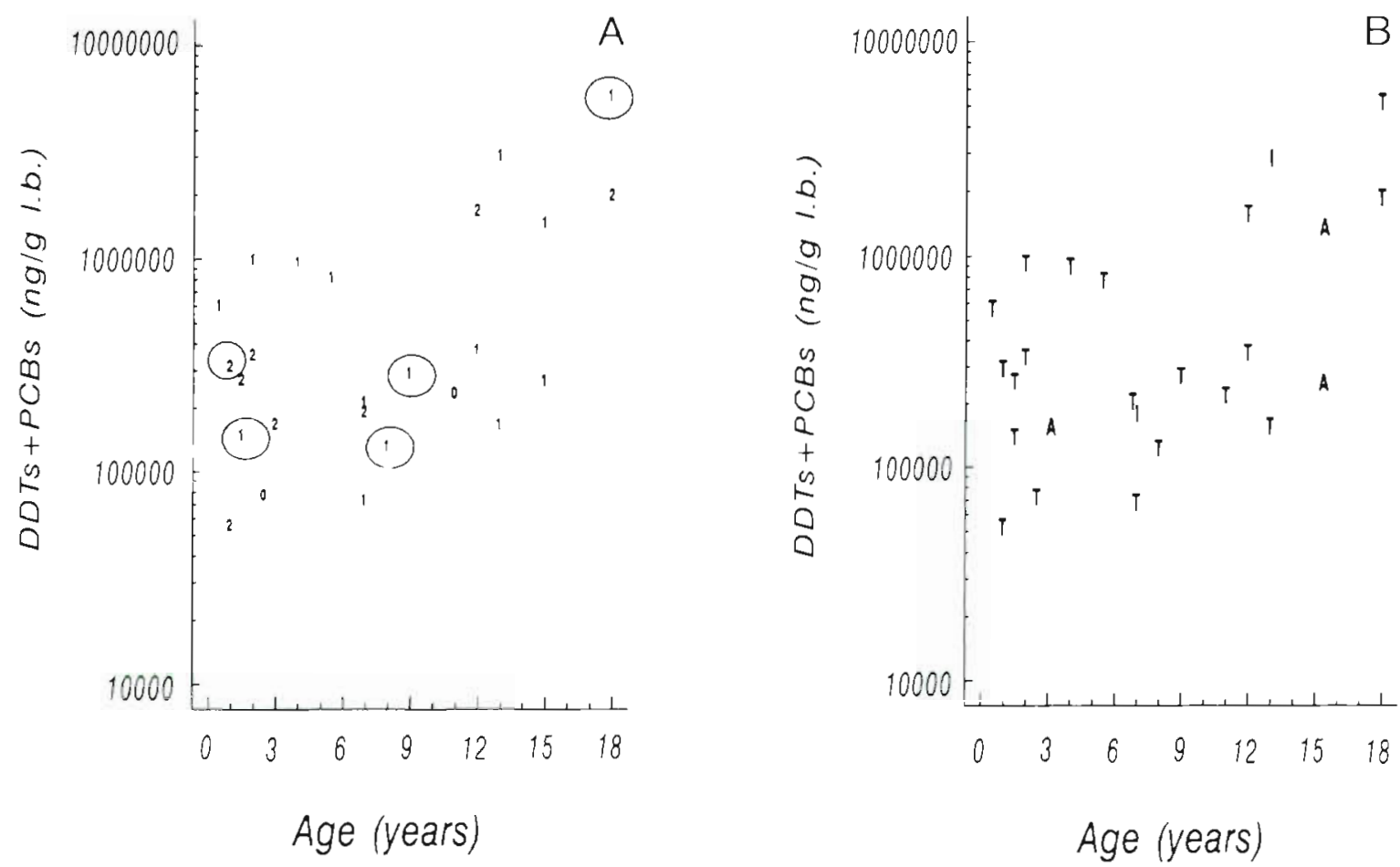

Fig. 2. Stenella coeruleoalba. Concentrations of organochlorines in brain, blubber, muscle and liver in relation to age (A) Showing sex (0: sex unknown, 1: male, 2: female) and cause of death (circle: dolphins dying as a result of accidents). (B) Showing locality of stranding (T: Thyrrhenian Sea, A: Adriatic Sea, I: Ionian Sea) 
hypotheses. In both cases, the females had a similar physiological pattern to males of the same age.

In interpreting the results of Fig. 2A, it should be borne in mind that there were no data on the history of the dolphins, such as where they had lived, when they reached physical and sexual maturity, and how many times females had been pregnant. The site and year of stranding should also be considered. Site is important because Mediterranean dolphins move in relatively limited areas of the Mediterranean Sea (Bearzi et al. 1992. Cagnolaro \& Notarbartolo di Sciara 1992) Not all coasts of the Mediterranean have the same human impact. There is generally a direct correlation between human exploitation of the coast and rivers and water pollution. In Italy, the most polluted seas are the Ligurian and northern
Adriatic. There is much industry in the Ligurian area as well as intensive farming and greenhouses. The sea is heavily contaminated with organochlorines from the nearby Rhone estuary (Mendola et al. 1977, Renzoni et al. 1986). The northern Adriatic can almost be regarded as a closed sea receiving the waters of rivers such as the Po with its high organochlorine levels (Galassi et al. 1981, Serman \& Serman 1992). The year of stranding is important in view of the epidemics and die-oft phenomena mentioned above (Bortolotto et al. 1992, Aguilar \& Raga 1993).

Some of the numbers in Fig $2 \mathrm{~A}$ representing the sexes are circled to indicate dolphins dying as a result of accidents ( 2 bled to death from injuries to the caudal fin, 1 died of a fractured skull, 1 starved because its

Table 4. Stenella coeruleoalba. Concentrations of organochlorines (ng $\mathrm{g}^{-1} \mathrm{~d} . \mathrm{w}$.) in relation to year of death. EOM\%: percentage extracted organic matter; SD: standard deviation

\begin{tabular}{|c|c|c|c|c|c|c|c|c|c|c|c|c|}
\hline \multicolumn{13}{|c|}{ Dolphins stranded before 1990} \\
\hline & \multicolumn{3}{|c|}{$\begin{array}{c}\text { Blubber } \\
\mathrm{EOM} \%=80 ; \mathrm{SD}=0\end{array}$} & \multicolumn{3}{|c|}{$\begin{array}{c}\text { Liver } \\
\text { EOM } \%=18 ; \mathrm{SD}=0\end{array}$} & \multicolumn{3}{|c|}{$\begin{array}{c}\text { Muscle } \\
\mathrm{EOM}^{*}=17 ; \mathrm{SD}=2\end{array}$} & \multicolumn{3}{|c|}{$\begin{array}{c}\text { Brain } \\
\text { EOM }=43 ; \mathrm{SD}=3\end{array}$} \\
\hline & HCB & DDTs & PCBs & $\mathrm{HCB}$ & DDTs & $\mathrm{PCBS}$ & $\mathrm{HCB}$ & DDTs & PCBS & $\mathrm{HCB}$ & DDTs & PCBs \\
\hline No. of samples & 4 & 4 & 4 & 3 & 3 & 3 & 4 & 4 & 4 & 4 & 4 & 4 \\
\hline Arithmetic mean & 139 & 10302 & 21121 & 63 & 3884 & 6067 & 10 & 596 & 2207 & 145 & 1192 & 2983 \\
\hline Median & 123 & 7116 & 20279 & 62 & 4861 & 6452 & 8 & 511 & 1378 & 92 & 1061 & 3075 \\
\hline Mode & 16 & 4905 & 9319 & 21 & 623 & 1432 & 7 & 233 & 1617 & 27 & 760 & 1512 \\
\hline Geometric mean & 85 & 8521 & 18921 & 52 & 2653 & 4568 & 9 & 501 & 741 & 95 & 1105 & 2728 \\
\hline $\mathrm{SD}$ & 126 & 7996 & 10804 & 43 & 2898 & 4455 & 5 & 396 & 2131 & 153 & 540 & 1366 \\
\hline Minımum & 16 & 4905 & 9319 & 21 & 623 & 1432 & 7 & 233 & 741 & 27 & 760 & 1512 \\
\hline \multirow[t]{5}{*}{ Maximum } & 294 & 22071 & 34607 & 106 & 6167 & 10317 & 18 & 1128 & 5331 & 370 & 1886 & 4270 \\
\hline & \multicolumn{9}{|c|}{ Dolphins stranded in 1990 and 1991} & & & \\
\hline & \multirow{2}{*}{\multicolumn{3}{|c|}{$\begin{array}{c}\text { Blubber } \\
\text { EOM } \%=74 ; \mathrm{SD}=19\end{array}$}} & \multirow{2}{*}{\multicolumn{3}{|c|}{$\begin{array}{c}\text { Liver } \\
\text { EOM\% }=21 ; S D=19\end{array}$}} & \multirow{2}{*}{\multicolumn{3}{|c|}{$\begin{array}{c}\text { Muscle } \\
\mathrm{EOM} \%=9 ; \mathrm{SD}=4\end{array}$}} & \multirow{2}{*}{\multicolumn{3}{|c|}{$\begin{array}{c}\text { Brann } \\
\text { EOM\% }=43 ; \mathrm{SD}=7\end{array}$}} \\
\hline & & & & & & & & & & & & \\
\hline & $\mathrm{HCB}$ & DDTs & PCBs & $\mathrm{HCB}$ & DDTs & PCBs & $\mathrm{HCB}$ & DDTs & PCBs & $\mathrm{HCB}$ & DDTs & PCBs \\
\hline No. of samples & 12 & 12 & 12 & 8 & 8 & 8 & 7 & 7 & 7 & 5 & 5 & 5 \\
\hline Arithmetic mean & 1639 & 113741 & 184225 & 422 & 27223 & 58132 & 54 & 1829 & 6712 & 71 & 3633 & 12756 \\
\hline Median & 475 & 67861 & 121770 & 149 & 25359 & 36650 & 13 & 2060 & 4757 & 32 & 3197 & 8622 \\
\hline Mode & 407 & 61409 & 78107 & 79 & 7528 & 21161 & 12 & 1043 & 4008 & 25 & 1934 & 5670 \\
\hline Geometric mean & 756 & 71392 & 121950 & 206 & 14916 & 31675 & 26 & 1512 & 5141 & 49 & 3010 & 8602 \\
\hline SD & 2773 & 107597 & 175365 & 483 & 23404 & 62471 & 61 & 1067 & 5510 & 67 & 2567 & 14127 \\
\hline Minimum & 192 & 14790 & 26695 & 50 & 2116 & 4824 & 5 & 582 & 2070 & 18 & 1320 & 2839 \\
\hline \multirow[t]{5}{*}{ Maximum } & 10091 & 349964 & 573262 & 1329 & 58611 & 172940 & 160 & 3051 & 16599 & 171 & 7861 & 37629 \\
\hline & \multicolumn{9}{|c|}{ Dolphins stranded after 1991} & & & \\
\hline & \multirow{2}{*}{\multicolumn{3}{|c|}{$\begin{array}{c}\text { Blubber } \\
\text { EOM } \%:=97: S D=3\end{array}$}} & \multirow{2}{*}{\multicolumn{3}{|c|}{$\begin{array}{l}\text { Liver } \\
\text { EOM } \%=24 ; \mathrm{SD}=18\end{array}$}} & \multirow{2}{*}{\multicolumn{3}{|c|}{$\begin{array}{c}\text { Muscle } \\
\text { EOM }^{\prime} \%=9 ; \mathrm{SD}=4\end{array}$}} & \multirow{2}{*}{\multicolumn{3}{|c|}{$\begin{array}{c}\text { Brain } \\
\mathrm{EOM} \%=45 ; \mathrm{SD}=7\end{array}$}} \\
\hline & & & & & & & & & & & & \\
\hline & $\mathrm{HCB}$ & DDTs & PCBS & $\mathrm{HCB}$ & DDTS & PCBs & $H C B$ & DDTs & PCBs & $\mathrm{HCB}$ & DDTs & PCBs \\
\hline No. of samples & 8 & 8 & 8 & 8 & 8 & 8 & 9 & 9 & 9 & 8 & 8 & 8 \\
\hline Arithmetic mean & 2076 & 51908 & 90949 & 202 & 21342 & 88982 & 65 & 2017 & 11035 & 144 & 3271 & 8328 \\
\hline Median & 922 & 35003 & 85377 & 114 & 4017 & 11511 & 51 & 2341 & 6840 & 40 & 1764 & 4491 \\
\hline Mode & 545 & 32277 & 77616 & 96 & 2598 & 7059 & 51 & 1097 & 3224 & 33 & 1130 & 4107 \\
\hline Geometric mean & 1062 & 41787 & 83844 & 113 & 7574 & 24271 & 41 & 1707 & 6613 & 71 & 2123 & 6083 \\
\hline $\mathrm{SD}$ & 2649 & 46901 & 42240 & 253 & 29575 & 122173 & 54 & 1110 & 12789 & 208 & 4201 & 8842 \\
\hline Minimum & 189 & 23665 & 46461 & 21 & 1464 & 3476 & 5 & 660 & 2091 & 29 & 961 & 3201 \\
\hline Maximum & 7916 & 165189 & 183817 & 798 & 82110 & 300993 & 156 & 3293 & 38439 & 607 & 13452 & 29245 \\
\hline
\end{tabular}


palate was damaged by a fishing hook, and the fifth starved with a plastic bag blocking its alimentary canal). These 5 dolphins were separated from the others because their death was unrelated to their health status; 4 of the 5 had organochlorine levels close to the mean for dolphins of the same age group, so that xenobiotic concentrations and cause of death do not seems to be related. This hypothesis is supported by the fact that the dolphin with the highest organochlorine levels of the whole 25 was the fifth of these dolphins.

In Fig. 2B, the points are marked $T$, $A$ or I to indicate that the dolphins were found on the coasts of the Tyrrhenian, Adriatic (off Apulia) or Ionian Seas, respectively. Most of the dolphins were found on the Tyrrhenian coasts, including the 2 with the highest and lowest input of PCBs+DDTs. Again there did not seem to be a relationship between organochlorine levels and site of stranding, contrary to expectations based on the fact that the northern Adriatic has heavier organochlorine pollution than the other 2 seas (Galassi et al. 1981, Serman \& Serman 1992)

The last factor to consider is the year of death. Since die-off of cetaceans, presumably due to viral infections such as Morbillivirus, occurred in 1990 and 1991, we separated the data into 3 periods: before 1990, 1990 and 1991 and after 1991 (Table 4). We also separated the data of the different tissues and the 3 organochlorines and applied Student's $t$-test to the ariumetic medn, standard deviution and number of samples. All tissues from dolphins stranded in 1990 and 1991 showed significantly higher levels of all xenobiotic compounds than tissues from dolphins stranded before 1990 (blubber HCB $p<0.01$, DDTs and PCBs $p<0.001$; liver all $p<0.01$; muscle HCB and PCBs $p<0.01$, DDTs $p<0.001$; brain HCB not significant, DDTs $p<0.01$, PCBs $p<0.05$ ), except for HCB in brain. The only significant differences found between the same variables in 1990 and 1991 and after 1991 were for HCB in liver $(p<0.001)$ and PCBs in muscle $(p<0.05)$ The fact that after 1991 organochlorine concentrations were not much less than in the period of the epidemic suggests that the viral infection continued.

These results confirm those of Aguilar \& Borrell (1994a) who found levels of organochlorines up to 3 times higher in specimens of Stenella coeruleoalba with Morbillivirus infection at the time of death than in biopsied dolphins which were presumably in good health. The levels found by these authors in infected dolphins were 5 times higher than ours for PCBs and 4 times higher for DDTs, reaching $846 \mu \mathrm{g} \mathrm{g}^{-1}$ l.b. (SD $618 \mu \mathrm{g} \mathrm{g}^{-1}$ ) for PCBs and $456 \mu \mathrm{g} \mathrm{g}^{-1}$ L.b. (SD $413 \mu \mathrm{g}$ $\mathrm{g}^{-1}$ ) for DDTs. The control samples from biopsied Spanish dolphins (Aguilar \& Borrell 1994b) were also much higher than ours (Marsili \& Focardi 1996)

\section{CONCLUSIONS}

The age of 62 specimens of Stenella coeruleoalba found stranded along the Italian coasts between 1988 and 1994 was determined by tooth analysis, and a growth curve was plotted for these dolphins in the Mediterranean. The equation of the curve was $Y=$ $200 /\left[1+e^{[0.201-03115 X)}\right]$ where $Y$ is body length in $\mathrm{cm}$ and $X$ age in $y r$.

Accumulation of organochlorines seems to depend on many parameters, such as sex, age, nutrition and health. A high correlation was found between contaminant levels in 25 dolphins of known age and year of death. Organochlorine levels were particularly high in the years 1990 and 1991, which coincided with an epidemic of Morbillivirus in the Mediterranean. It is not yet clear whether the disease was a cause or a result of the high levels of fat-soluble xenobiotics in these cetaceans (Aguilar \& Borrell 1994a).

Acknowledqements. The authors thank the 'Centro Studi Cetacei' and the 'European Cetacean Society', in particular Prof. Tommaso Renieri, Mr Fabrizio Cancelly, Dr Alessandro Bortolotto and Mr Leandro Stanzani for providing the samples. They also thank Drs Christina Lockyer and Nuria Calzada for teaching the method of age determination in small cetaceans, the Human Pathology Institute of Polyclinic Umberto I of Roma for the collaboration in tooth section preparation, and Prof. Eros Bacci and Dr Carlo Gaggi for working out the growth curve equation. This is publication No. 60 of the Italıan 'Centro Studi Celacei'.

\section{LITERATURE CITED}

Addison RF (1989) Organochlorines and marine mammal reproduction. Can J Fish Aquat Sci 46:360-368

Aguilar A, Borrell A (1994a) Abnormally high polychlorınated biphenyl levels in striped dolphins (Stenella coeruleoalba) affected by the 1990-1992 Mediterranean epizootic. Sci Total Environ 154:237-247

Aguilar A, Borrell A (1994b) Assessment of organochlorine pollutants in cetaceans by means of skin and hypodermic biopsies. In: Fossi MC, Leonzio C (eds) Nondestructive biomarkers in vertebrates. Lewis Publishers, Florida, p $245-267$

Aguilar A, Raga JA (1993) The striped dolphin epizootic in the Mediterranean Sea. Ambio 22(8):524-528

Alzieu C, Duguy R (1979) Teneurs en composés urganochlorés chez les cétacés et pinnipedes frequentant les cótes françaises. Oceanol Acta 2(1):107-120

Baker JR (1989) Pollution-associated uterine lesions in grey seals from the Liverpool Bay area and the Irish Sea. Vet Rec 125(20):500-503

Bearzi G, Notarbartolo di Sciara G, Bonomi L 11992 ) Bottlenose dolphins off Croatia: a socio-ecological study. Europ Res Cet 6:130-136

Bergman A, Olsson M, Relland S (1986) High frequency of skeletal deformities in skulls of the Baltic grey seal. Comm Meet Int Coun Explor Sea doc CM-ICES/N:15 1-7

Borrell A (1993) Dinamica dels contaminants organoclorats en la balena d'aleta, el cap d'olla d'aleta llarga i el dofi llistat d'aigues atlantiques 1 mediterranies. Tesi di Doctoral, 
Departament de Biologia Animal, Facutat de Biologia, Universitat de Barcelona

Borrell A, Aguilar A (1991) Were PCB levels abnormally high in striped dolphins affected by the western Mediterranean die-off? Europ Res Cet 5:88-92

Bortolotto A, Casini L. Stanzan L (1992) Dolphins mortality along the southern Italian coast (June-September 1991). Aquat Mamm 18(2):56-60

Brouwer A, Reijnders PJH, Koeman JH (1989) Polychlorinated biphenyl $(\mathrm{PCB})$ - contaminated fish induces vitamin $A$ and thyroid hormone deficiency in the common seal (Phoca vitulina). Aquat Toxicol 15:99-106

Bryden MM (1986) Age and growth. In: Bryden MM, Harrison $\mathrm{R}$ (eds) Research on dolphins. Clarendon Press, Oxford, p 211-224

Cagnolaro L, Di Natale A, Notarbartolo di Sciara G (1983) Guide per il riconoscimento delle specie animali delle acque lagunari e costiere italiane. Cetacei. Consiglio Nuzionale delle Ricerche, Collana del progetto finalizzato 'Promozione della qualita' dell'ambiente' Roma Vol 9 , p $1-186$

Cagnolaro L, Notabartolo di Sciara G (1992) Attività di ricerca sui Cetacei e loro status di conservazione in Italia. Boll Mus Ist Biol Univ Genova 56-57:53-85

Casini C (1995) Determinazione dell'eta' in Stenella coeruleoalba (Cetacea, Delphinidae). Tesi di Laurea in Scienze Biologiche, Anno Accademico 1994/95, Universita 'La Sapienza' di Roma

Domingo M, Pumarola M, Visa J, Marco A, Ferrer L, Plana J, Kennedy $S$ (1991) Morbillivirus infection in striped dolphins (Stenella coeruleoalba) in the Mediterranean Sea. Europ Res Cet 5:97

Dunker $J$ C, Hillebrand MTJ, Zeinstra T, Boon JP (1989) Indıvidual chlorinated biphenyls and pesticides in tissues of some cetacean species from the North Sea and the Atlantic Oceani tissue distribution and biotransformation. Aquat Mamm 1ว(3):95-124

Fossi MC, Marsili L, Leonz10 C. Notarbartolo di Sciara G. Zanardelli M. Focardi S (1992) The use of non-destructive biomarker in Mediterranean cetaceans: preliminary data on MFO activity in skin biopsy. Mar Pollut Bull 24(9): $459-461$

Galassi S, Gandolfi G, Pacchetti G (1981) Chlorinated hydrocarbons in fish from the river Po (Italy). Sci Total Environ $20: 231-240$

Geraci JR (1989) Clinical investigation of the 1987-88 mass mortality of bottlenose dolphins along the US central and South Atlantic coats. Final report to (US) NMFS, US Navy and the Marine Mammal Commission. Univ of Guelph, Ontario

Helle E, Olsson M, Jensen S (1976a) DDT and PCB levels and reproduction in ringed seal from the Bothnian Bay. Ambio 5:188-189

Helle E, Olsson M, Jensen S (1976b) PCB levels correlated with pathological changes in seal uteri. Ambio 5:261-263

Kasuya T (1972) Growth and reproduction of Stenella coeruleoalba based on the age determunation by means of dentinal growth layers. Sci Rep Whales Res Inst Tokyo 24:57-79

Kasuya T (1976) Reconsideration of life history parameters of the spotted and striped dolphins based on cemental layers. Sci Rep Whales Res Inst Tokyo 28:73-106

Kawai S, Fukushima M (1981) Relation between the lipid composition and the concentrations of organochlonne compounds in the various organs of struped dolphins (Stenella coeruleoalba). In: Fujiyama $T$ (ed) Studies on the levels of organochlorine compounds and heavy metals in the manne organisms. University of the Ryukyus, Okinawa, p 85-96
Le Boeuf BJ, Bonnell MK (1971) DDT in California sea lions. Nature 234:108-110

Lockyer C, Smellie CG, Goodall RPN, Cameron IS (1981) Examination of teeth of Commerson's dolphin (Cephaiorhynchus commersoni) for age determination. J Zool Lond 195:123-131

Loganathan BG, Tanabe S, Tanaka H, Watanabe S, Miyazaki $N$. Amano M. Tatsukawa R (1990) Comparison of organochlorine residue levels in the striped dolphin from western north Pacific, 1.978-79 and 1986. Mar Pollut Bull 21(9):435-439

Loose LD, Pitman KA, Bentitz KF, Silkworth JB (1977) Polychlorinated biphenyl and hexachlorobenzene induced humoral immunosuppression. J Reticuloendo thel Soc 22 : 253-271

Marcovecchio JE, Gerpe MS, Bastida RO, Rodriguez DH, Morón SG (1994) Environmental contamination and marine mammals in coastal waters from Argentina: an overview. Sci Total Environ 154:141-151

Marsili L, Focardi S (1996) Organochlorıne levels in subcutaneous blubber biopsies of fin whales (Balaenoptera physalus) and striped dolphins (Stenella coeruleoalba) from the Mediterranean Sea. Environ Pollut 91(1):1-9

Marsili L, Focardi S (1997) Chlorinated hydrocarbon (HCB, DDTs and PCBsi levels in cetaceans stranded along the Italian coasts: an overview. Environ Monit Assess (in press)

Martineau D, Beland P, Desjardins C, Lagacé A (1987) Levels of organochlorine chemicals in tissues of beluga whales (Delphinapterus leucas) from the St Lawrence Estuary, Quebec, Canada. Arch Environ Contam Toxicol 16 $137-147$

Mendold JT, Risebrough RW, Blondel J (1997) Contamınation de l'avifaune camarguaise par des residues organchlorés. Environ Pollut 13:21-31

Murphy PG (1972) Sulphuric acid for the clean-up of animal tissues for analysis of acid stable hydrocarbon residues. $\checkmark$ Am Org Analyt Chem 55:1360-1362

Myrick AC Jr, flohn AA, Sloan PA, Kimura M, Stanley DD (1983) Estimating age of spotted and spinner dolphins (Stenella attenuata and Stenella longirostris) from teeth. NOAA Technical Memorandum NMFS-SWFC 30:17

Nishiwaki M, Yagi T (1953) On the age and growth of the theeth in a dolphn (Prodolphinus caeruleoalbus). Sci Rep Whales Res Inst Tokyo 13:135-155

Notarbartolo di Sciara G, Demma M (1994) Guida dei mammiferi marini del Mediterraneo. Franco Muzzio Editore, Padova

Olsson M (1978) PCB and reproduction among Baltic seals. Finn Game Res 37:40-45

O'Shea TJ, Brownell RL, Clark DR, Walker WA, Gay ML, Lamont TG (1980) Organchlorine pollutants in small cetaceans from the Pacific and South Atlantic Oceans, November 1968 - June 1976. Pestic Monit J 14:35-46

Perrin WF, Myrick AC (1980) Growth of Odontocetes and Sirenians: problems in age determination. In: Perrin WF, Myrick AC (eds) Age determination of toothed whales and sirenians. Rep Int Whal Comm. (Special Issue 3):1-50

podestà M, Marsili L, Focardi S, Manfred. MT, Mignone W. Genchi C (1992) Ricerche patologiche, parassitologiche e sulla presenza di xenobiotici in Stenella coeruleoalba (Meyen, 1833) (Mammalia Cetacea). Attı Soc Ital Scı Nat Museo Civ Storia Nat 133(9): 101-112

Renzoni A, Focardi S, Fossi C, Leonzio C, Mayol J (1986) Comparison between concentrations of mercury and other contaminants in eggs and tissues of Cory's shearwater 
Calonectris diomedea collected on Atlantic and Mediterranea Islands. Environ Pollut (Series A) 40:17-35

Serman D, Serman A (1992) Marine mammal conservation status and research in the eastern Adriatic Sea. Europ Res Cet 6:54-55

Tanabe S, Tenaka H, Maruyama K, Tatsukawa R (1981b) Ecology and bioaccumulation of Stenella coeruleoalba. Elimination of chlorinated hydrocarbons from mother striped dolphins (Stenella coeruleoalba) through parturition and lactation. In: Fujiyama $T$ (ed) Studies on the levels of organochlorine compounds and heavy metals in the marine organisms. University of the Ryukyus, Okinawa, p 115-121

Tanabe S, Tatsukawa R (1992) Chemical modernization and vulnerability of cetaceans: increasing toxic threat of organochlorine contaminants. In: Walker $\mathrm{CH}$, Livingstone DR (eds) Persistent pollutants in marne ecosystem. Pergamon Press, Oxford, 7, p 161-177

Tanabe S, Tatsukawa R, Maruyama K, Miyazaki N (1982) Transplacental. transfer of PCBs and chlorinated hydrocarbon pesticides from the pregnant striped dolphin (Stenella coeruleoalba) to her fetus. Agric Biol Chem 46:1249-1254

This article was submitted to the editor
Tanabe S, Tatsukawa R, Tanaka H, Maruyama K, Miyazakı N, Fujiyame T (1981a) Distribution and total burdens of chlorinated hydrocarbons in bodies of striped dolphins (Stenella coeruleoalba). Agric Biol Chem 45(11):2569-2578

Tanabe S, Watanabe S, Kan H, Tatsukawa R (1988) Capacity and mode of PCB metabolism in small cetaceans. Mar Mamm Sci 4:103-124

Van Bressen MF, Visser IKG, De Swart RL, Örvell C, Stanzani L, Androukaki E, Siakavara K (1993) Dolphin morbillivirus infection in different parts of the Mediterranean Sea. Arch Virol 129:235-242

Vos JG, Luster MI (1989) Immune alterations. In: Kimbrough RD, Jensen AA (eds) Halogenated biphenyls, terphenyls, naphtalenes, dibensodioxins and related products. Elsevier Amsterdam, p 295-232

Watanabe S, Shimada T, Nakamura S, Nishiyama $N$, Yamashita N, Tanabe S, Tatsukawa R (1989) Specific profile of liver microsomal cytochrome P-450 in dolphin and whales. Mar Environ Res 27:51-65

Zakharov VM, Yablokov AV (1990) Skull asymmetry in the Baltic grey seal: effects of environmental pollution. Ambio 19(5):266-269

Manuscript first received: November 18, 1996

Revised version accepted: April 3, 1997 